\title{
PENGANIAYAAN DILIHAT DARI SUDUT PANDANG
}

FILSAFAT MANUSIA

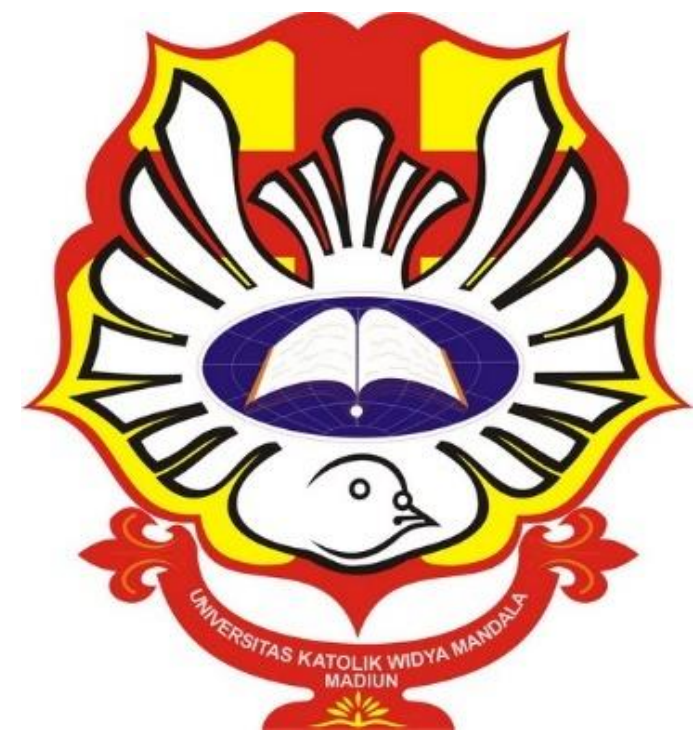

Ditulis oleh :

Abrian Nathanael Pangestu (41417001)

FAKULTAS TEKNIK

PROGRAM STUDITEKNIK INDUSTRI

UNIVERSITAS KATOLIK WIDYA MANDALA SURABAYA

KAMPUS MADIUN

DESEMBER 2019 


\begin{abstract}
ABSTRAK
Kasus kejahatan pada saat ini sangatlah banyak ditemui di kehidupan kita sehari-hari salah satunya adalah kekerasan dan kekerasan ini banyak dialami oleh wanita salah satunya adalah tindakan penganiayaan yang dilakukan oleh beberapa warga NTT terhadap seorang gadis, kjadian ini dipicu karena adanya dugaan bahwa korban dituduh mencuri,padahal tuduhan itu belum terbukti kebenarannya, karena kesal warga langsung menghakiminya dan menyisaknya tampa mencari tahu terlebih dahulu kebenaranya. Dan kini kasusunya telah ditangani oleh pihak berwajib, dan nkasusu ini akan di idern tifikasi menurut filsafat manusia apakah tindakan tersebut benar dan penyimpangan apa saja yang terdapat di dalam kejadian tersebut
\end{abstract}

Keyword : Kekerasan, penganiayaan, filsafat manusia

\title{
PENDAHULUAN
}

\section{LATAR BELAKANG}

Filsafat manusia merupakan ilmu yang membahas mengenai makna menjadi manusia, manusia sendiri adalah mahluk yang senantiasa berfikir yang mulanya heran terhadap suatu kejadian atau fenomena yang terjadi di alam semesta ini, yang pada akhirnya dengan kemampuan berfikir ini manusia dapan menemukan jawaban yang logis atas segala pertanyaan yang selama ini mereka fikirkan, sedangkan filsafat juga membantu manusaia untuk mencari kebenaran fenomena yang ada saat ini atau fenomena masalalu, yang memberikan pengertian tentang cara hidup, dan pandangan hidup sebagai seorang manusia, mengajarkan tentang etika dan moral dalam kehidupan ,mengembangkan kemampuan dalam hal menalar dan juga membebaskan manusia dari belenggu berfikir yang sempit

Pada saat ini banyak manusia yang memiliki moral yang bisa dikatakan buruk mereka mengaku memiliki akal tetapi pada kenyataannya apa yang mereka perbuat 
tidak mencerminkan perilakunya sebagai manusia yang memiliki akal budi, maka dari itu mahasiswa teknik industri pada saat ini dibekali dengan mata kuliah filsafat manusia agar setelah lulus mereka memiliki etika dan moral yang baik di masyarakat juga agar bias memanusiakan manusaia, pada tugas ini mahasisiwa ditugaskan untuk mencari suatu kasus yang kemudian mengidentifikasi kasus tersebut dan juga mengkaitkannya dengan filsafat manusia,dan di harapkan mahasisiwa dapat memberikan tanggapan mengenai kasus tersebut dan dapat mengaplikasikannya di kehidupan bermasyarakat agar mahasiswa lulusan teknik industri dapat berperilaku baik di masyarakat dan juga memiliki moral yang baik supaya mahasiswa tidak hanya memiliki pengetahuan yang luas saja melainkan juga memiliki perilaku yang baik dalam masyarakat

Dalam kenyataan sehari-hari banyak perbuatan atau sikap manusia yang tidak mencerminkan keberadaanya sebagai manusia mereka sering berbuat spontan atu langsung berbuat tanpa memeikirkan sebab dan akibat dari perbuatan mereka tersebut, dan tanpa mengedepankan akal pekiran mereka bahkan ada beberapa perbuatan mereka yang dapat dikatakan lebih rendah dari binatang mereka idak segan-segan melakukan kekerasan terhadap sesamanya bahkan sampai ada beberapa kasus mereka membunuh tampa belas kasihan terhadap sesamanya

\section{TEORI}

\section{INTELEK DAN KEHENDAK MANUSIA}

Dalam kasus ini saya akan menghubungkannya dengan teori intelek, kehendak, dan dinamika manusia, intelek sendiri adalah soal mengerti dan kehendak adalah soal kemauan dalam hal ini manusia diberikan kemampuan intelek dan kemampuan berfikir itulah yang membedakan kita dengan mahluk lainnya,seharusnya dengan diberi kemampuan untuk berfikir manusia seharusnya mampu membedakan perbuatan yang baik dan buruk tidak serta merta melakukan tindakan secara spontan tanpa memikirkan apakah tindakan itu pantas dilakukan atau tidak, dan manusia juga 
di anugerahi dengan akalbudi itu juga yang membedakan kita dengan mahluk lainya akalbudi dengan akal budi itulah tercipta moral dan akhlak yang akan membimbing kita kearah yang baik tetapi tidak jarang orang berbuat tidak baik itu karena moral mereka mulai luntur dan hati nurani mereka mulai tumpul karena jarang mereka asah jarang mereka tidak peka terhadap hati nurani mereka itu biasanya diakibatkan oleh lingkungan atau cara didik yang kurang baik pada saat kecil, itulah yang membuat hati nurani mereka tidak peka atau tumpul

Kehendak adalah soal kemauan seseorang tidak akan melakukan sesuatu tanpa ada kemauan jika kita akan melakukan sesuatu jika kita memiliki keamauan jika kita sudah memiliki kemauan maka kita akan menghendaki perbuatan tersebut dan akan melakukan berbuatan yang kita kehendaki tersebut, dalam hal ini sebagai manusia yang memiliki intelek dan kemampuan berfikir kita tidak serta merta melakukan kehendak tampa memikirkan berbuatan tersebut terlebih dahulu, namu di era sekarang banya orang yang melakukan berbuatan sesuai kehendaknya sendiri tanpa berfikir terlebih dahuludan itu membuat berkurangnya rasa kemanusian pada saat ini,terus apa bedanya kita dengan mahluk-mahluk yang tidak di anugrahi akal budi

Manusia disatu pihak emiliki kebebasan tetapi di lain pihak juga tergantung. Ketika memutuskan suatu perbutan manusia bebas untuk melakukannya, tetapi setelah itu manusai harus tunduk pada apa yang telah diputuskannya itu dan juga bertanggungjawab atas apa yang telah diperbuat itu, dalam kebebasan itu tidak sertamerta membuat kita bebas untuk melakukan segala hal tanpa ada batasannya melainkan kebebasan untuk melakukan suatu hal tanpa ada tekana dari pihak manapun dan dalam buatannya kita harus tetap mengedepankan akal sehat untuk melakukan suatu perbuatan

Antara intelek dan kehendak manusai sangatlah berkaitan erat karena dengan intelek kita dapat memikirkan terlebih dahulu dan dengan kehendak kita akan memiliki kemauan untuk berbuat seatu dengan bigitulah seharusnya seorang manusia 
melakukan segala hal,segala berbuatan harus kita fikirkan terlebih dahulu sebelum kita memutuskan untuk melakukan tindakan tersebut, jangan berkehendak terlebih dahulu dan melakukan perbuatan tanpa memikirkan terlebih dahulu apa kensekuensi yang akan kita terima dan akibat apa yang akan kita dapat

Pada hakekatnya manusia manusia dalah suatu keharusan dan kebebasan kebebasan ini dad dalam satu kesatuan substansial,denangan kata lain manusia itu kebebasan yang mengharuskan,dan keharusan yang membebaskan didalam kebebasan termuat kebebasan, begitulah hakekat manusia mereka memiliki kodrat yang telah di tetapkan tetapi mereka juga memiliki sutau kebebasan untuk menentukan jaln yang mereka pilih

\section{DINAMIKA MANUSIA SEBAGAI REALITAS}

Apakah arti kata dinamika ?dinamika berasal dari kata Yunani yang berarti dapat atu mampu, dari kata ini terbentuk kata dinamityang artinya kemampuan, kekuatan. Dari kata benda dinamis di bentuk kata kata dinamika yang memiliki arti mempunyai kekuatan,punya daya gerak,demikian juga manusia,manusia manusia itu merupakan dinamika karena manusia selalu bergerak dan terus tumbuk pertumbuhan itu bukan hanya sebatas pertumbuhan fisik saja melainkan juga pertumbuhan sikis dan juga pertumbuhan mental,dan itu juga membentuk manusia untuk dapat berfikir secara dewasa,

Dalam taraf fisiologi sejak timbulnya sebagai satu sel manusia tidak perbah berhnti bergerak.sel bertumbuh mengadakan deverensiasi, mengadakan organ-organ dan akhirnya menjadi bayi. Terus bertumbuh, berkembang, terus mempertahankan diri,organ-organ bekerja, darah terus bergerak mengalir dan sebagainya. Bagaiman dalam taraf spiritual ?pertama janganlah lagi manusia spiritual dipisahkan dari badaniah. Tidak ada kerohanian manusia tanpa kejasmanian manusia, jadi seharusnya tidak hanya jasmaniah kita saja yang berkembang melainkan kerohanian kita harus berkembang karena dengan kerohanian itulah kita akan dibimbing ke hal yang 
baik,jika rohani kita terus berkembang maka kita akan semakin dekat dengan kebaikan

Mengenai keaktifan dalam kesadaran,harus kita bedakan menjadi dua aspek yaitu aspek koknitif dan aspek efektif. Dan disini harus di bedakan bagian keinderaan dan bagian rohani tetapi tidak berpisah-pisah semua itu merupakan kesatuan. Dalam kesadaran kita selalu aktif jadi dinamika yang selau aktif secara actual, kita terus menerus menangkap, baik dengan indra maupun dengan budi, demikian juga kita selalu menghendaki selau menerima ini dan itu, dinamika manusia berarti kekuatan yang bergerak menggerakan, dan mendorong

Untuk lebih menyelami dinamika manusia atau manusia sebagai dinamika haruslah di ingat bahwa manusia itu jasmani dan rohani, pada dasarnya kejasmanian mulai denagan badan kita sendiri itu merupakan perantara media tetapi bersama itu juga merintangi,sekarang lebih nampaklah dinamika kita berusaha melangkahi rintangan tetapi rintangan itu tidak akan dad habisnya maka kehidupan manusia dalah pergulatan dan perintang,maka dalam hal ini usaha manusia akan berhasil sangat jauh tetapi tidak munkin ada titik puncak dalm suatu perjuangan kitajadi manusia sebagai suatu dinamika rus terus bergerak dan berkembang budak hanya badaniah tetapi jiga rohaniah agar pergerak kita seimbang tidak berat sebelah

Dalam hal ini dinamika dalam realitas kehidupan manusia sangatlah berkaitan erat dengan pertiumbuhan dan perkembangan manusia itu sendiri karna sejatinya manusia ituterus tumbuh dan berkembangbaik dari segi jasmani maupun rohaninya dan kedinamisan itulah yang membawa manusia menjadi lebih baik karena mereka akan terus bertumbuh dan berkembang menuju ke hal yang lebih baik jika mereka mengimbangi kedua pertumbuhan tersebut mereka akan menjadi pribadi yang memiliki akal budi yang baik, karna dengan akal budi itulan kita akan menjadi manusia yang seutuhnya, akal budilah yang mencerminkan kita sebagai manusia dan itulah yang membedakan kita dengan mahluk hidup lain 


\section{PEMBAHASAN}

\section{KASUS}

Pada saat ini tindak kriminal sangat beragam jenisnya mulai dari perampokan, bembunuhan, pemerkosaan, dan lain sebagainya bahkan tidak jarang kasus-kasus tersebut melibatkan wanita sebagai korbannya, dan motif dibalik tindak kriminal tersebutpun beragam mulai dari faktor ekonomi ,cemburu,dan banyak lagi faktorfaktor lain yang mendorong tindak criminal tersebut. Di Indonesia sendiri juga telah banyak tindak kriminal yang terjadi, salah satu yang menyebabkan banyaknya tindak criminal adalah faktor ekonomi,karena faktor ekonomi yang rendah itulah yang mengakibatkan tingginya angka kriminalitas di Indonesia, dengan rendahnya perekonomian maka menyebabkan kurangnya pendidikan yang terjadi di Indonesia

Tetapi bukan itusaja yang mengakibatkan tingginya angka kriminalitas di Indonesia rendahnya pendidikan moral yang ditanamkan sejak dini juga menjadi salah satu hal yang penting yang harus dilakukan sejak dini, karena dengan cara didik yang baik dan lingkungan yang baik itu juga dapat mengakibatkan,perilaku yang baik juga yang terbentuk dan itu dapat meminimalisir angka kriminal yang akan terjadi, karena dengan moral yang baik kita akan berfikir panjang dulu sebelum melakukan suatu hal, dan mempertimbangkannya terlebih dahulu apakan perbuatan itu baik atau tidak

Salah satu contoh kasus yang kan saya ambil adalah penyiksaan seorang gadis di NTT yang dituduh mencuri, kejadian ini bermula ketika ada beberapa warga yangmenuduh korban mencuri perhiasan milik salah satu warga, dan kemudian mereka membawa korban ke posyandu dan mulai menghakiminya tangan korban di ikat kebelakang dan tali ikatan tersebut dikaitkan dengan kuda-kuda atap bangunandan salah satu warga yang diduga adalah kepala dusun menariknya keatas sehingga membuat gadis korban kesakitan, korban terus di introgasi tetapi korban hanya bias menangis kesakitan, dan ada beberapa pelaku yang menendangnnya dari 
belakang, kekerasan itu dilakukan hamper 30 menit,dan dilakukannya di depan umun, dan disaksikan banyan yak warga mulai dari anak-anak hingga orang dewasa

Pelaku di tuduh tanpa ada bukti yang kuat bahwa korban benar-benar melakukan pencuarian dan yang lebih parahlagi mereka menghakimi korban di hadapan umum mereka tidak mengintrogasi saja tepi mereka melakukan tindak kekerasan terhadap korban, tetapi kasus ini telah ditangani oleh pihak berwajib pada kasus ini telah ditetapkan tujuh warga sebagai pelaku dalam penyiksaan tersebut, kasus inipun segera ditangani karena video penyiksaan tersebut sudah viral di media sosialdan juga youtube, selain menetapkan ketujuh tersangka polisi juga menyita beberapa barang bukti berupa kursi, tali, dan beberapa potong kayu yang digunakan untuk menghukum korban

\section{ARGUMEN}

Dalam kasus ini korban mengalami tindak kekerasan karena korban dituh mencuri, tetapi apakah benar dengan melakukan tindak kekerasan tersebut maka korban akan mengakui perbuatanya jelas tidak ,sedangkan mereka melakukan penuduhan terhadap korban tanpa bukti yang kuat bakwa korban melakukan pencurian, disini manusia memiliki intelek atau kemampuan untuk berfikir dan juga kehendak lantas apakah pebuatan tersebut dapat dikatan bahwa kita memiliki kemampuan berfikir, jelas tidak jika mereka memiliki intelek yang baik mereka tidak akan melakukan indakan tersebut, mereka akan memikirkan terebih dahulu tindakan mereka itu baik atau buruk benar atau salah

Tetapi pada kenyataannya mereka memalukan tindakan yang dapat dikatakan spontan tak memikirkannya terlebih dahulu, mereka mengedepankan emosi tanpa menggunakan intelek yang mereka miliki tanpa berfikir terlebih dahulu, seharusnya mereka tidak melakukan tindakan tersebut karena masalah tersebut dapat diselesaikan dengan baik-baik, selain itu bukti yang dituduhkan terhadap korbanpun belum tentu 
benar karena bukti yang mereka bawa pun tidak ada, selain itu ada pihak berwajib yang bisa menangani kasus tersebut, tidak perlu main hakim sendiri

Manusia sebagai dinamika sebagai realitas seharusnya manusia sebagai dinamika terus bergerak kearah kebaikan terus berkembang menuju kebaikan dalam kasus penyiksaan kali ini jelas perbuatan yang dilakukan menyimpang dari arah menuju lebih baik, seharusnya mereka dapat berfikir secara jernih tanpa harus melakukan kekerasan untuk menyelesaikan sebuah masalah, karena kita adalah ciptaan yang diberi akal budu seharusnya kita menggunakan akal budi tersebut sebelum melakukan suatu perbuatan 


\section{DAFTAR PUSTAKA \& REFERENSI}

Dewantara, A. (2019). Diktat Kuliah Filsafat Manusia.

Sumber berita diambil dari : https://news.okezone.com/read/2019/11/01/340/2124779/kronologi-gadis-di-ntt-disiksahingga-digantung-gara-gara-dituduh-mencuri 